\title{
PENGARUH PENDAPATAN DAN LINGKUNGAN SOSIAL TERHADAP KEPUTUSAN PEMBELIAN SECARA TAQSITH
}

\author{
Kustin Hartini, Inggriani \\ IAIN Bengkulu \\ E-mail: kustinhartini@gmail.com, inggriani@gmail.com
}

\begin{abstract}
Income and social environment are factors that can influence purchasing decisions. The purpose of this study was to determine the effect of income and social environment on purchasing decisions in taqsith. This type of research with a quantitative approach. The sampling technique uses a purposive sampling technique with a total sample of 66 people. The data analysis method uses multiple linear analysis with the help of SPSS. From the results of the T Test and F Test show that partially income variables significantly influence the purchase decision taqsith with a probability value (Sig) $0.017<$ (a) 0.05. Social environment variables also have a significant effect on taqsith purchasing decisions with a probability value (Sig) $0.033<(\alpha)$ 0.05. Simultaneously income and social environment significantly influence the purchase decision in taqsith and this can be seen from the probability value (Sig) $0,000<(\alpha) 0.05$.
\end{abstract}

Keywords: Revenue, Social Environment, Purchasing decisions

Abstrak : Pendapatan dan lingkungan sosial merupakan faktor yang dapat mempengaruhi keputusan pembelian. Tujuan penelitian ini untuk mengetahui pengaruh pendapatan dan lingkungan sosial terhadap keputusan pembelian secara taqsith. Jenis penelitian dengan pendekatan kuantitatif. Tehnik pengambilan sampel menggunakan teknik purposive sampling dengan jumlah sampel sebanyak 66 orang. Metode analisis data mengunakan analisis linier berganda dengan bantuan SPSS. Dari hasil Uji $T$ dan Uji F menunjukkan bahwa secara parsial variabel pendapatan berpengaruh signifikan terhadap keputusan pembelian secara taqsith dengan nilai probabilitas (Sig) $0,017<(\alpha)$ 0,05. Variabel lingkungan sosial juga berpengaruh signifikan terhadap keputusan pembelian secara taqsith dengan nilai probabilitas (Sig) $0,033<(\alpha)$ 0,05. Secara simultan pendapatan dan lingkungan sosial berpengaruh signifikan terhadap keputusan pembelian secara taqsith dan hal ini dapat dilihat dari nilai probabilitas (Sig) 0,000 < ( $\alpha$ ) 0,05.

Kata kunci: Pendapatan, Lingkungan Sosial, Keputusan Pembelian

\section{A. PENDAHULUAN}

Perkembangan gaya hidup saat ini sangat cepat, sehingga kadang masyarakat mengalami kesulitan untuk memenuhi keinginan yang terus bertambah. Keinginan tersebut biasanya seiring dengan meningkatnya pendapatan yang diperoleh. Pendapatan pribadi merupakan pendapatan dari hasil usaha yang diperoleh individu atau kelompok rumah tangga dan digunakan untuk memenuhi kebutuhan sehari-hari. ${ }^{1}$ Kebutuhan manusia terkait dengan segala sesuatu yang harus dipenuhi, dalam perspektif ekonomi Islam, semua barang dan jasa yang membawa pengaruh pada kemaslahatan disebut dengan kebutuhan manusia. ${ }^{2}$

Menurut Robert M.Z. Lawang menyebutkan pendapatan adalah semua yang diterima oleh seseorang dalam satu bulan atau satu tahun yang dapat diukur dengan nilai ekonomi. ${ }^{3}$

\footnotetext{
${ }^{1}$ Mahyu Danil, "Pengaruh Pendapatan Terhadap Tingkat Konsumsi Pada Pegawai Negeri Sipil Dikantor Bupati Kabupaten Bireuen”, Jurnal Manajemen, Vol. IV No. 7, 2013, hlm. 35

${ }^{2}$ Mardian Suryani dan Siti achira, "Gaya Hidup Hedonisme Konsumsi Ditinjau dari Perspektif Ekonomi Islam”, Al-Intaj, Vol.V No.2, 2019, hlm. 238-250

${ }^{3}$ Khairiah, Kesempatan Mendapatkan Pendidikan, (Yogyakarta: Pustaka Pelajar, 2018), hlm. 124
} 
Menurut Ardiani Ika, pendapatan kecil memang akan mengurangi keleluasaan orang untuk melakukan pengeluaran, namun jika dikelola dengan benar berdasarkan prioritas, sangat dimungkinkan tujuan keuangan keluarga dapat tercapai. Sebenarnya cukup banyak individu dengan pendapatan atau penghasilan yang tidak cukup besar tetapi merasa cukup dan bahagia. Hal tersebut terjadi karena individu memiliki kemampuan yang sangat baik dalam merencanakan, menganggarkan, mengelola, mengendalikan dan menyimpan untuk investasi, konsumsi dan lain sebagainya. ${ }^{4}$

Sukirno menggambarkan hubungan antara pendapatan, konsumsi, dan tabungan menjadi 3 yaitu: Pertama, pada pendapatan yang rendah rumah tangga harus menggunakan harta atau tabungan masa lalu untuk membiayai pengeluaran konsumsinya. Kedua, kenaikan pendapatan menaikan pengeluaran konsumsi, biasanya pertambahan pendapatan adalah lebih tinggi dari pada pertambahan konsumsi. Ketiga, pada pendapatan yang tinggi rumah tangga menabung, disebabkan pertambahan pendapatan selalu lebih besar dari pertambahan konsumsi maka pada akhirnya rumah tangga tidak "Mengorek Tabungan" lagi. ${ }^{5}$

Selain pendapatan, peningkatan keinginan juga dapat dipengaruhi oleh lingkungan sosial dimana merupakan lingkungan kemasyarakatan yang mempunyai kaitan erat dengan kehidupan sehari-hari. Menurut Setiadi dan Kolip yang dimaksud dengan lingkungan sosial adalah Tempat atau suasana dimana sekelompok orang merasa sebagai anggotanya, seperti lingkungan kerja, lingkungan RT, lingkungan pendidikan, lingkungan pesantren, dan sebagainya. Jadi lingkungan sosial adalah semua orang dan suasana tempat yang dapat mempengaruhi kita baik secara langsung maupun tidak langsung.: ${ }^{6}$ Pada dasarnya keinginan itu mendorong seseorang untuk berperilak dan perilaku merupakan dasar dalam membuat keputusan pembelian.

Keputusan pembelian merupakan proses panjang yang dilakukan pembeli bermula jauh sebelum seorang membeli suatu produk dan berlangsung lama sesudahnya. Proses yang terjadi disaat seorang ingin melakukan keputusan pembelian yaitu mencari informasi, melakukan evaluasi alternative, keputusan pembelian dan perilaku pasca pembelian. ${ }^{7}$

Ada beberapa faktor yang dapat mempengaruhi keputusan pembelian diantaranya adalah : faktor budaya, faktor sosial, faktor pribadi dan faktor psikologi. ${ }^{8}$ Sebuah keputusan yang diambil oleh pembeli, hakekatnya adalah rangkaian dari sejumlah keputusan yang dibuat sebelumnya. Setiap keputusan pembelian memiliki struktur atas variabel-variabel keputusan diantaranya adalah metode pembayaran. Konsumen harus mengambil keputusan tentang cara pembayaran produk yang dibeli, apakah secara tunai, kredit atau cara yang lainnya.

Berdasarkan latar belakang tersebut, maka peneliti tertarik menganalisis pengaruh pendapatan dan lingkungan sosial terhadap keputusan pembelian secara taqsith pada masyarakat Desa Pagardin Kecamatan Dempo Utara Kota Pagar Alam.

\footnotetext{
${ }^{4}$ Andartika Rosa, "Pengaruh Financial Knoeledge, Tingkat Pendapatan Terhadap Perilaku Pengelolaan Uang Dengan Self Control Sebagai Variabel Medias”, Jurnal Ilmiah, Vol. V No. 2, 2018, hlm. 34

${ }^{5}$ Sadono Sukirno, Makro Ekonomi Teori Pengantar, (Jakarta: Raja Grafindo Persada, 2006), hlm. 109

${ }^{6}$ Riana Monalisa Tamara, "Peranan Lingkungan Sosial Terhadap Pembentukan Sikap Peduli Lingkungan Peserta Didik Di Sma Negeri Kabupaten Cianjur”, Jurnal Pendidikan Geografi, Vol. XVI No. 1, 2016, hlm. 45 2013), hlm. 95

${ }^{7}$ Mulyadi Nitisusastro, Perilaku Konsumen Dalam Perspektif Kewirausahaan, (Bandung: Alfabeta.

8 Kotler Dan Armstrong, Prinsip-Prinsip Pemasaran, (Jakarta: PT Gelora Aksara Pratama, 2001), hlm. 197
} 


\section{B. METODE PENELITIAN}

Jenis penelitian ini adalah penelitian lapangan (Field research). Penelitian lapangan merupakan penelitian kuantitatif yang merupakan metode untuk menguji teori-teori tertentu dengan cara meneliti hubungan antar variabel. Variabel-variabel ini diukur (biasanya dengan instrumen penelitian) sehingga data yang terdiri dari angka-angka dapat dianalisis berdasarkan prosedur statistik. ${ }^{9}$ Penelitian ini menggunakan pendekatan kuantitatif asosiatif kausal. Penelitian asosiatif kausal ini adalah jenis pendekatan penelitian yang bersifat menanyakan hubungan yang bersifat sebab akibat antara variabel yang mempengaruhi (independen) dan variabel yang dipengaruhi (dependen). ${ }^{10}$

Populasi dalam penelitian ini adalah Masyarakat Desa Pagardin RT 03 RW 09 Kecamatan Dempo Utara Kota Pagar Alam. Tehnik pengambilan sampel yang digunakan adalah purposive sampling yaitu tehnik penentuan sampel dengan pertimbangan tertentu. Penelitian ini mengunakan data primer dengan menyebar kuisioner. Tehnik pengukuran dengan mengunakan skala Likert.

Instrumen penelitian yang berupa kuesioner diuji dengan menggunakan uji validitas dan uji reliabilitas. Uji validitas digunakan untuk mengukur sah atau valid tidaknya suatu kuisioner. Suatu kuesioner valid jika pertanyaan pada kuesioner mampu mengungkapkan sesuatu yang akan diukur oleh suatu kuesioner tersebut, adapun uji validitas ini menggunakan korelasi Correted Item-Total Correlation. Jika hasil r-hitung > r-tabel maka instrumen pertanyaan dalam kuesioner tersebut valid. Reliabilitas artinya dapat dipercaya juga dapat diandalkan. Sehingga beberapa kali di ulang pun hasilnya akan tetap sama (konsisten). Jika kuesioner telah valid dan reliabel maka kuesioner dapat disebarkan pada responden. Untuk uji reliabel menggunakan teknik Cronbach Alpa, jika nilai Cronbach Alpa > 0,50 maka dikatakan reliabel.

\section{Uji Asumsi Dasar}

Uji normalitas digunakan untuk mengkaji data variabel bebas (X) dan data variabel (Y) pada persamaan regresi yang dihasilkan, yaitu berdistribusi normal dan berdistribusi tidak normal. Untuk mengetahui populasi berdistribusi normal atau tidak, dalam penelitian ini menggunakan uji kolmogorov-smirnov dengan bantuan komputer program SPSS 16 for windows.

Uji homogenitas dilakukan untuk mengetahui apakah data dalam variabel $\mathrm{X}$ dan $\mathrm{Y}$ tersebut homogen. Ketentuan, jika nilai signifikansi $>\alpha(0,05)$ maka data tersebut homogeny dan sebaliknya jika nilai signifikansi $<\alpha(0,05)$ maka data tersebut tidak homogeny. ${ }^{11}$

\section{Uji Asumsi Klasik}

Uji multikolinearitas dapat dideteksi dengan menganalisis matrik korelasi variabelveriabel independen atau dengan menggunakan perhitungan nilai tolerance dan variance inflation faktor (VIF) tidak lebih dari 10 dan nilai tolenrance tidak kurang dari 0,1 maka model regresi dapat dikatakan bebas dari masalah Multikolinearitas.

\section{Analisa Regresi Linear Berganda}

Analisa Regresi Linear Berganda digunakan untuk mengetahui keeratan hubungan

\footnotetext{
${ }^{9}$ Juliansyah Noor, Metodologi Penelitian. Skripsi,Tesis,Disertai,Dan Karya Ilmiah, (Jakarta: Prenadamedia, 2011), hlm. 38

${ }^{10}$ Sugiono, Metode Penelitian Kuantitatif Dan Kualitatif Dan $r \& d$, (Bandung: Al-fabeta, 2013), hlm. 37

${ }^{11}$ Syofian Siregar, Metode Penelitian Kuantitatif, (Jakarta: Kecana, 2013), hlm. 55
} 
antara variabel keputusan pembelian secara taqsith (Y) dengan variabel pendapatan (X1) dan lingkungan sosial (X2). Adapun bentuk persamaanya adalah sebagai berikut ${ }^{12}$ :

$Y=\alpha+\beta 1 X 1+\beta 2 X 2+e$

Dengan:

$\mathrm{Y}=$ Variabel keputusan pembelian

$\alpha=$ Konstanta

$\beta 1, \beta 2=$ Koefisien regresi

$\mathrm{X} 1=$ Variabel Pendapatan

$\mathrm{X} 2$ = Variable Lingkungan Sosial

\section{Uji T}

$\mathrm{e}=$ Variabel penggangu

Uji $\mathrm{t}$ digunakan untuk mengetahui besarnya pengaruh masing-masing variabel independen secara parsial terhadap variabel dependen. Jika dari hasil uji t dengan nilai Sig $<\alpha$ $(0,05)$ maka hipotesis yang dirumuskan diterima.

Untuk mengkaji pengaruh variabel independen terhadap variabel dependen secara parsial dapat dilihat dari rumusan hipotesis sebagai berikut:

H1. Pendapatan berpengaruh signifikan terhadap keputusan pembelian secara taqsith

H2. Lingkungan Sosial berpengaruh signifikan terhadap keputusan pembelian secara taqsith

\section{Uji F}

Untuk mengetahui signifikan pengaruh secara simultan dilakukan pengujian hipotesis secara bersama-sama digunakan alat uji F. Jika hasil $\mathrm{F}_{\text {hitung }}>\mathrm{F}_{\text {tabel, }}$ atau nilai sig $<\alpha(0,05)$ maka hipotesis diterima. Untuk mengkaji pengaruh variabel independen terhadap variabel dependen secara simultan dapat dilihat dari rumusan hipotesis sebagai berikut:

H3. Pendapatan dan Lingkungan Sosial secara simultan berpengaruh dan signifikan terhadap keputusan pembelian secara taqsith

\section{Koefisien Determinasi $\left(\mathbf{R}^{2}\right)$}

Koefisien Determinasi $\left(\mathrm{R}^{2}\right)$ digunakan untuk mengetahui seberapa besar persentase kontribusi pengaruh Pendapatan dan Lingkungan Sosial terhadap keputusan pembelian. Dalam memberikan interprestasi secara sederhana terhadap angka indeks korelasi pengaruh Pendapatan (X1), dan Lingkungan Sosial (X2) terhadap keputusan pembelian (Y) pada umumnya digunakan sebagai berikut:

Tabel 1. Pendoman Untuk Memberikan Interpensi Koefisien Determinasi

\begin{tabular}{|l|l|l|}
\hline O & Proporsi Atau Internal Koefisien & Keterangan \\
\hline 1 & $0 \%-19,99 \%$ & Sangat Rendah \\
\hline 2 & $20 \%-39,99 \%$ & Rendah \\
\hline 3 & $40 \%-59,99 \%$ & Sedang \\
\hline 4 & $60 \%-79,99 \%$ & Kuat \\
\hline 5 & $80 \%-100 \%$ & Sangat Kuat \\
\hline
\end{tabular}

Sumber: Siregar, Syofian ${ }^{13}$

\footnotetext{
${ }^{12}$ Iqbal Hasan, Pokok-Pokok Materi Statistik 2, (Jakarta: PT Bumi Aksara, 2012), hlm. 225

${ }^{13}$ Syofian Siregar, Statistik Parametrik..., hlm. 377
} 


\section{HASIL DAN PEMBAHASAN \\ 1. Deskripsi Responden}

Responden yang menjadi obyek penelitian ini adalah Masyarakat Desa Pagardin RT 03 RW 09 Kecamatan Dempo Utara Kota Pagar Alam. Jumlah responden dalam penelitian ini 66 responden. Berdasarkan data yang diperoleh dari karakteristik responden, responden terdiri dari: a. Deskripsi Responden Berdasarkan Pekerjaan

Tabel .2 Pekerjaan Responden

\begin{tabular}{|c|c|c|}
\hline Pekerjaan & Frekuensi & $\begin{array}{c}\text { Persentase } \\
(\boldsymbol{\%})\end{array}$ \\
\hline Pelajar & 10 & $15 \%$ \\
\hline Ibu Rumah Tangga & 16 & $24 \%$ \\
\hline PNS & 15 & $23 \%$ \\
\hline Wiraswasta & 10 & $15 \%$ \\
\hline Karyawan Swasta & 15 & $23 \%$ \\
\hline Total & 66 & $100 \%$ \\
\hline
\end{tabular}

Sumber: Data Diolah, 2020

Berdasarkan tabel diatas, dapat diketahui pekerjaan responden sebagai pelajar 10 orang dengan persentase $15 \%$, bekerja sebagai Ibu Rumah Tangga 16 orang dengan persentase $24 \%$. Bekerja sebagai PNS 15 orang dengan persentase $23 \%$, Wiraswasta 10 orang dengan persentase $15 \%$ dan yang bekerja sebagai Karyawan Swasta 15 orang dengan persentase $23 \%$. Hal ini menunjukkan bahwa masyarakat yang menjadi responden terbanyak adalah yang bekerja sebagai Ibu Rumah Tangga.

b. Deskripsi Responden Berdasarkan Umur.

Adapun data yang didapat peneliti berdasarkan usia responden pada masyarakat Desa Pagardin Kecamatan Dempo Utara Kota Pagar Alam yang melakukan pembelian secara Taqsith yang diambil sebagai responden sebagai berikut:

Tabel .3 Usia Responden

\begin{tabular}{|c|c|c|}
\hline Usia & Frekuensi & $\begin{array}{c}\text { Persentase } \\
(\boldsymbol{\%})\end{array}$ \\
\hline $17-27 \mathrm{Th}$ & 15 & $23 \%$ \\
\hline $27-37 \mathrm{Th}$ & 25 & $38 \%$ \\
\hline $37-50 \mathrm{Th}$ & 26 & $39 \%$ \\
\hline Total & 66 & $100 \%$ \\
\hline
\end{tabular}

Sumber: Data Diolah 2020

Berdasarkan pada tabel diatas, dapat diketahui usia responden penelitian ini yang berusia 17-27 tahun sebanyak 15 orang dengan persentase $23 \%$, yang berusia 27-37 tahun 25 orang dengan persentase $38 \%$, dan yang berusia 37-50 tahun 26 orang dengan persentase $39 \%$. Ini menunjukkan bahwa usia responden terbanyak yang berusia 37-50 tahun.

\section{Uji Validitas}

Pengujian ini dilakukan untuk mengetahui kevalidan suatu kuesioner. Untuk tingkat validitas, dilakukan uji signifikan dengan membandingkan nilai $r$ hitung dengan $r$ tabel. Dari hasil uji validitas dengan SPSS dapat diketahui bahwa semua pertanyaan yang ada dalam 
kuesioner adalah valid. Semua item dalam pertanyaan variabel pendapatan (X1), lingkungan sosial (X2) dan variabel keputusan pembelian (Y) menunjukkan bahwa nilai Pearson Corelation lebih besar dari $r$ kritis. Dan semua item pertanyaan menunjukkan nilai signifikansi pada level $5 \%$ sehingga tidak ada item pertanyaan yang dibuang dan dapat digunakan pada keseluruhan pengujian.

\section{Uji Reliabilitas}

Uji reliabilitas dalam penelitian ini adalah menggunakan rumus Cronbach Alpha, dimana dikatakan reliabel jika Cronbach Alpha $>0,05$. Berdasarkan hasil uji reliabilitas dengan SPSS dapat diketahui bahwa seluruh variabel memiliki nilai Cronbach Alpha yang lebih besar dari nilai 0,05. Untuk X1 nilai Cronbach Alpha sebesar 0.684, X2 nilai Cronbach Alpha sebesar 0.730, dan Y nilai Cronbach Alpha sebesar 0.561. sehingga item pernyataan tersebut dinyatakan reliabel.

\section{Uji Normalitas}

Tabel 4. Hasil Uji Normalitas Data

One-Sample Kolmogorov-Smirnov Test

\begin{tabular}{|cc|r|}
\hline & & \multicolumn{2}{|c|}{$\begin{array}{c}\text { Unstandardized } \\
\text { Residual }\end{array}$} \\
\hline \multicolumn{2}{|c|}{$\mathrm{N}$} & 66 \\
Normal & Mean & .0000000 \\
Parameters & & Std. Deviation \\
Most & Absolute & 1.77598620 \\
Extreme & Positive & .100 \\
Differences & Negative & .100 \\
Kolmogorov-Smirnov Z & -.085 \\
Asymp. Sig. (2-tailed) & .812 \\
\hline
\end{tabular}

Sumber: Data Primer Diolah SPSS, 2020

Berdasarkan tabel 4 diatas hasil uji normalitas menunjukkan bahwa nilai signifikan secara variabel lebih besar dari 0.05 maka nilai residual tersebut berdistribusi normal.

\section{Uji Homogenitas}

Pengujian homogenitas menggunakan lavane test dengan ketentuan jika sig $>\alpha$, maka variansi setiap sampel sama (homogen). Data hasil pengujian dapat dilihat pada tabel berikut ini:

Tabel 5. Hasil Uji Homogeniitas

\begin{tabular}{|c|r|r|r|r|r|c|}
\hline & $\begin{array}{c}\text { Levene } \\
\text { Statistic }\end{array}$ & df1 & df2 & Sig. & $\alpha$ & Ket \\
\hline Pendaptan & 2.011 & 7 & 56 & .070 & 0,05 & Homogen \\
\hline $\begin{array}{c}\text { Lingkungan } \\
\text { Sosial }\end{array}$ & .646 & 7 & 57 &. $\mathbf{7 1 6}$ & 0,05 & Homogen \\
\hline
\end{tabular}

Dari hasil tabel 5 diatas dapat diketahui signifikansi masing-masing variabel lebih besar dari 0,05 . Hal ini berarti bahwa seluruh variabel adalah homogen, artinya sampel yang diambil dari populasi yang sama dapat mewakili dari jumlah populasi yang ada. Angka Levene Statistic menunjukkan semakin kecil nilainya maka semakin besar homogenitasnya. 


\section{Uji Asumsi Klasik}

\section{a. Uji Multikolinearitas}

Uji multikolinearitas dalam penelitian ini dilakukan dengan melihat nilai tolerance dan varian infontion factor (VIF). Jika nilai VIF tidak lebih kurang dari 10,00 dan nilai tolerance tidak kurang dari 0,1 maka dinayatakan tidak terjadi multikolinearitas. Berikut ini hasil uji multikolinearitas:

\section{Tabel 6. Hasil Uji Multikolinearitas}

\section{Coefficients $^{\mathrm{a}}$}

\begin{tabular}{|r|r|r|}
\hline \multirow{2}{*}{\multicolumn{2}{|c|}{ Model }} & \multicolumn{2}{|c|}{ Collinearity Statistics } \\
\cline { 2 - 4 } & Tolerance & \multicolumn{1}{|c|}{ VIF } \\
\hline 1 (Constant) & & \\
Pendapatan & .847 & \\
Lingkungan & .847 & \\
Sosial & & \\
\hline
\end{tabular}

Sumber: Data Primer Diolah SPSS, 2020

Berdasarkan tabel 6 di atas, hasil uji Variance inflation faktor (VIF) pada hasil output SPSS tabel Coefficients, masing-masing variabel independen memiliki nilai VIF Pendapatan yaitu 1,181 dan Lingkungan Sosial yaitu 1,181 masing-masing variabel bebas memiliki nilai VIF $<10$ dan nilai tolerance Pendapatan yaitu 0,847 dan Lingkungan Sosial 0,847 masing-masing variabel bebas memiliki nilai tolerance > 0,01 maka dapat disimpulkan bahwa model regresi linear berganda tidak terdapat multikolinearitas antara variabel terikat dengan variabel bebas sehingga dapat digunakan dalam penelitian.

b. Analisis Regresi Linear Berganda

Analisis dalam penelitian ini menggunakan model regresi berganda untuk mengetahui pengaruh beberapa variabel independen terhadap variabel dependen serta untuk mengetahui arah hubungan pengaruh variabel tersebut. Berikut ini hasil dari analisis regresi linear berganda.

Tabel 7. Hasil Analisi Regresi

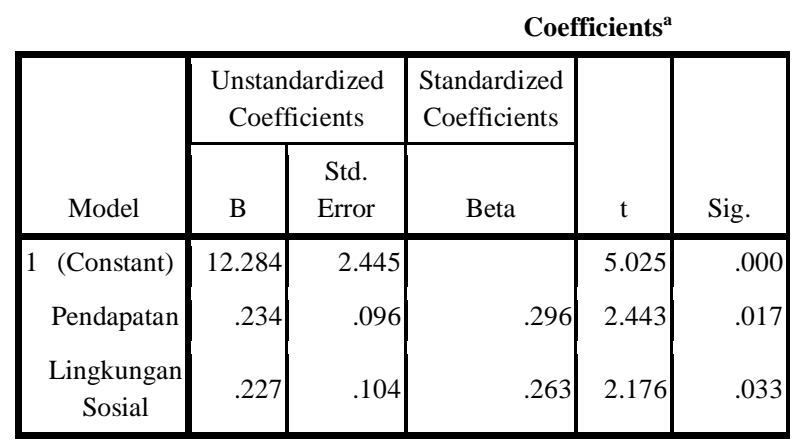

Sumber: Data Primer diolah SPSS, 2020

Berdasarkan tabel 7 hasil analisi regresi diatas, maka dapat dibuat persamaan regresi linear seperti berikut ini:

$$
\mathrm{Y}=12,284+0,234 \mathrm{X}_{1}+0,227 \mathrm{X}_{2}+\mathrm{e}
$$




\section{c. Uji T}

\section{Pengujian Hipotesis pertama}

Berdasarkan tabel 7 diatas dapat diketahui untuk variabel pendapatan (X1) diperoleh nilai signifikan (sig.) sebesar 0,017. Berarti nilai (sig) $(0,017<(\alpha) 0,05$ hal ini menunjukkan bahwa $\mathrm{H}_{1}$ yang menyatakan bahwa pendapatan berpengaruh signifikan terhadap keputusan pembelian secara taqsith diterima.

\section{Pengujian Hipotesis Kedua}

Berdasarkan tabel diatas dapat diketahui untuk variabel lingkungan sosial (X2) diperoleh nilai signifikan (sig.) sebesar 0,033 . Berarti nilai (sig) $(0,033<(\alpha) 0,05$ hal ini menunjukkan bahwa $\mathrm{H}_{2}$ yang menyatakan bahwa lingkungan sosial berpengaruh signifikan terhadap keputusan pembelian secara taqsith diterima.

\section{d. Uji F}

\section{Tabel 8. Hasil Uji F}

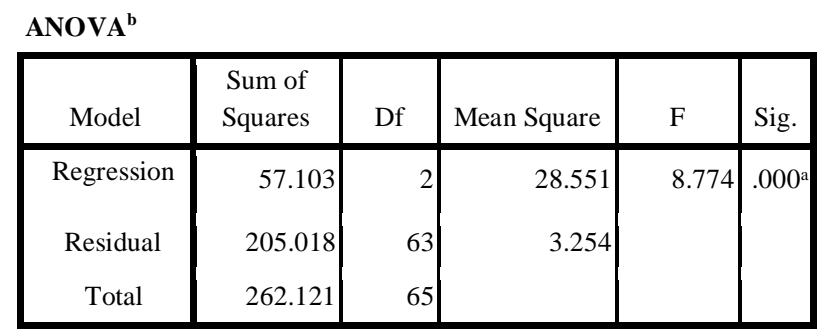

Sumber: Data Primer diolah SPSS, 2020

\section{Pengujian Hipotesis Ketiga}

Berdasarkan table 8 diatas dapat diketahui untuk variabel pendapatan (X1) dan lingkungan sosial (X2) secara simultan diperoleh nilai signifikan (sig.) sebesar 0,000. Berarti nilai (sig) $\left(0,000<(\alpha) 0,05\right.$ hal ini menunjukkan bahwa $\mathrm{H}_{3}$ yang menyatakan bahwa secara simultan variabel pendapatan dan lingkungan sosial berpengaruh signifikan terhadap keputusan pembelian secara taqsith diterima.

\section{e. Uji Determinasi $\left(\mathrm{R}^{2}\right)$}

Berdasarkan tabel 9 Uji Determinasi dibawah ini dapat diketahui nilai R Square sebesar 0,218 atau $21,8 \%$. Hal ini menunjukkan bahwa dalam penelitian ini keputusan pembelian secara taqsith dipengaruhi variabel pendapatan dan variabel lingkungan sosial sebesar 21,8\% dan sisanya $78,2 \%$ dipengaruhi oleh faktor-faktor lainnya yang tidak digunakan dalam penelitian ini

\section{Tabel 9. Hasil Uji Determinasi}

\begin{tabular}{|c|c|r|r|r|}
\hline \multicolumn{7}{|c|}{ Model Summary $^{\mathbf{b}}$} \\
\hline Model & $\mathrm{R}$ & R Square & $\begin{array}{c}\text { Adjusted R } \\
\text { Square }\end{array}$ & $\begin{array}{l}\text { Std. Error of } \\
\text { the Estimate }\end{array}$ \\
\hline 1 & $.467^{\mathrm{a}}$ & .218 & .193 & 1.804 \\
\hline
\end{tabular}

Sumber: Data Primer diolah SPSS, 2020 


\section{Pembahasan}

Keputusan pembelian merupakan proses panjang yang dilakukan pembeli bermula jauh sebelum seorang membeli suatu produk dan berlangsung lama sesudahnya. Proses yang terjadi disaat seorang ingin melakukan keputusan pembelian yaitu mencari informasi, melakukan evaluasi alternatif, keputusan pembelian dan perilaku pasca pembelian. ${ }^{14}$

Keputusan pembelian yang dikemukakan oleh para ahli. Menurut Setiadi: Pengambilan keputusan adalah proses pengintegrasian yang mengombinasikan pengetahuan untuk mengevaluasi dua perilaku alternatif atau lebih, dan memilih salah satu diantaranya. Hasil dari proses pengintegrasian ini adalah suatu pilihan yang disajikan secara kognitif sebagai keinginan berperilaku. ${ }^{15}$

\section{a. Faktor Yang Mempengaruhi Keputusan Pembelian}

1) Faktor Budaya

a) Kultur

Budaya (Culture) adalah penyebab paling mendasar dari keinginan dan perilaku seorang. Perilaku manusia dipelajari secara luas. Ketika tumbuh dalam masyarakat, seorang anak mempelajari nilai-nilai dasar, persepsi, keinginan, dan perilaku dari keluarga dan instusi penting lainnya. ${ }^{16}$

b) Sub Kultur

Menurut Kotler dan Armstrong sub budaya adalah kelompok orang dalam sistem nilai berdasarkan pengalaman dan situasi hidup yang sama. ${ }^{17}$

c) Kelas Sosial

Kelas sosial adalah kelompok yang terbuka untuk para individu yang memiliki tingkat sosial yang serupa. Dalam kelas sosial terjadi pembedaan masyarakat kedalam kelas-kelas secara bertingkat, ada kelas yang tinggi, ada kelas yang rendah. ${ }^{18}$

2) Faktor Sosial

a) Kelompok

Kelompok secara langsung mempengaruhi dan dimiliki seseorang disebut kelompok keanggotaan (membership graups). Beberapa diantaranya adalah kelompok primer yang memiliki interaksi regular tetapi informan seperti keluarga, teman-teman, tetangga, dan rekan kerja. Beberapa diantaranya kelompok sekunder, yang lebih formal dan memiliki lebih sedikit interaksi regular. Kelompok sekunder ini mencakup organisasi-organisasi seperti kelompok keagamaan, asosiasi profesional, dan serikat buruh. ${ }^{19}$

\footnotetext{
${ }^{14}$ Mulyadi Nitisusastro, Perilaku Konsumen Dalam Perspektif Kewirausahaan, (Bandung: Alfabeta, 2013), hlm. 95

${ }^{15}$ Morrisan, Perilaku Komunikasi Pemasaran Terpadu, (Jakarta: Kencana Prenada Media Group, 2010), hlm. 111

${ }^{16}$ Kotler Dan Armstrong, Prinsip-Prinsip Pemasaran, (Jakarta: PT Gelora Aksara Pratama, 2001), hlm.

${ }^{17}$ Kotler Dan Armstrong, Prinsip-Prinsip..., hlm. 197

${ }^{18}$ Etta Mamang Sangadji Dan Sopiah, Perilaku Konsumen, (Yogyakarta: C.V Andi Offset, 2013), hlm.

${ }^{19}$ Kotler Dan Armstrong, Prinsip-Prinsip..., hlm. 202-203
} 
b) Anggota Keluarga

Pengaruh yang lebih langsung terhadap perilaku pembelian sehari-hari adalah keluarga prokreasi (family of procration) seseorang, yakni pasangan hidup dan anak-anaknya. ${ }^{20}$ Keluarga adalah organisasi pembelian konsumen yang penting dalam masyarakat,dan pengaruh tersebut telah diteliti secara ekstensif. Orang pemasaran tertarik pada peran dan pengaruh seorang suami, istri maupun anak-anak dalam pembelian produk dan jasa yang berbeda. Pengaruh yang lebih langsung terhadap perilaku pembelian sehari-hari adalah keluarga. ${ }^{21}$

3) Faktor Pribadi

a) Pekerjaan

Pekerjaan seseorang mempengaruhi pola konsumsinya. Pekerja kasar cenderung membeli pakaian kerja kasar, sedangkan pekerja kantoran membeli setelan bisnis. Orang pemasaran mencoba mengidentifikasi kelompok-kelompok pekerja yang memilki minat yang rata-rata lebih tinggi pada produk dan jasa yang mereka hasilkan. ${ }^{22}$

b) Gaya Hidup

Gaya hidup (lifestyle) adalah pola hidup seseorang. Untuk memahami kekuatankekuatan kita mengukur dimensi-dimensi utama konsumen, activites (pekerjaan, hobi, belanja, olahraga, kegiatan sosial), interest (makanan, mode, keluarga, kreasi), dan opinions (mengenai diri mereka sendiri, masalah-masalah sosial, bisnis, produk). ${ }^{23}$ Gaya hidup mencakup sesuatu yang lebih dari sekedar kelas sosial atau keperibadian seseorang. ${ }^{24}$

4) Faktor Psikologis

a) Motivasi

Perilaku seseorang dimulai dengan adanya suatu motif yang menggerakkan individu dalam mencapai suatu tujuan. ${ }^{25}$ Seseorang memiliki banyak kebutuhan pada setiap waktu tertentu. Kebutuhan bersifat biologis. Keputusan yang demikian berasal dari psikologis berkaitan dengan tensi / ketegangan seperti rasa lapar, haus dan tidak nyaman. Motif atau dorongan adalah kebutuhan yang cukup mendorong seorang agar bertindak. Pemasaran kebutuhan tersebut akan mengurangi rasa ketegangan. ${ }^{26}$

b) Persepsi

Persepsi adalah proses pemilihan, pengorganisasian, dan penginterprestasian masukan informasi untuk menghasilkan makna. ${ }^{27}$ Seseorang yang termotivasi akan siap bertindak.

c) Keyakinan

Keyakinan adalah pemikiran deskriptif seseorang mengenai sesuatu. Orang pemasaran tertarik pada keyakinan yang dirumuskan mengenai produk dan jasa tertentu, karena keyakinan ini menyusun citra produk yang mempengaruhi keputusan pembelian. ${ }^{28}$

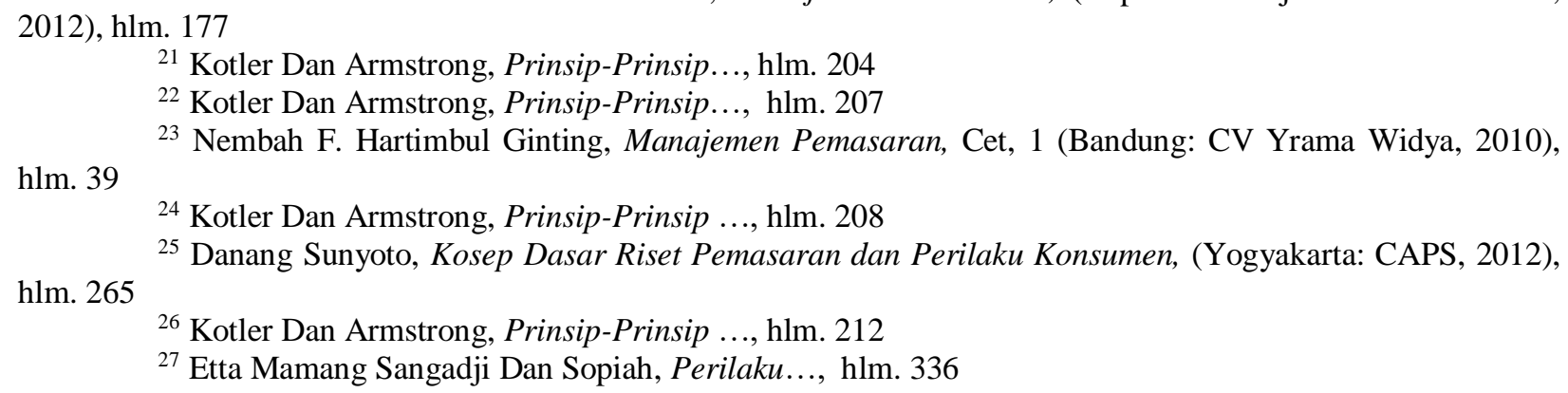

${ }^{21}$ Kotler Dan Armstrong, Prinsip-Prinsip..., hlm. 204

${ }^{22}$ Kotler Dan Armstrong, Prinsip-Prinsip..., hlm. 207

${ }^{23}$ Nembah F. Hartimbul Ginting, Manajemen Pemasaran, Cet, 1 (Bandung: CV Yrama Widya, 2010), hlm. 39

${ }^{24}$ Kotler Dan Armstrong, Prinsip-Prinsip ..., hlm. 208

${ }^{25}$ Danang Sunyoto, Kosep Dasar Riset Pemasaran dan Perilaku Konsumen, (Yogyakarta: CAPS, 2012), hlm. 265

${ }^{26}$ Kotler Dan Armstrong, Prinsip-Prinsip ..., hlm. 212

${ }^{27}$ Etta Mamang Sangadji Dan Sopiah, Perilaku..., hlm. 336

20 Thamrin Abdullah dan Francis Tantri, Manajemen Pemasaran, (Depok: PT Raja Grafindo Persada, 
Indikator Keputusan Pembelian

a) Pengenalan Masalah

b) Pencarian Informasi

c) Evaluasi Berbagai Alternatif

d) Keputusan pembelian

e) Perilaku pasca pembelian

Setiap keputusan pembelian memiliki struktur atas variabel-variabel keputusan diantaranya adalah metode pembayaran. Konsumen harus mengambil keputusan tentang cara pembayaran produk yang dibeli, apakah secara tunai, kredit(Tagsith) atau cara yang lainnya.

\section{b. Taqsith (Kredit)}

Taqsith (Kredit) secara bahasa berarti bagian, jatah atau membagi-bagi. Yang kemudian secara istilah dikatakan: mengkredit artinya adalah membayar hutang tersebut dengan cicilan yang sama pada beberapa waktu yang ditentukan. Dengan demikan, pengertian jual beli kredit secara istilah adalah menjual sesuatu dengan pembayaran tertunda dan dalam bentuk cicilan dalam waktu-waktu ditentukan. ${ }^{29}$ Fatwa-fatwa Taqsith (Kredit), diantaranya:

1) Fatwa lembaga dan ulama

Dalam kitab (Fatwa Lajna Daimah Lil Buhuts Wal Ifta') No: 9388, 13/123 disebutkan tentang jual beli Taqsith: jika barang dijual dengan harga lebih dari pada harga kontan tetapi harga tersebut dibatasi, maka tidak ada masalah. Entah dengan sekali tempo atau berkali-kali (Ditaqsith) selama dengan jangka waktu yang ditentukan. Kemudian dalam jual beli Taqsith apabila pembeli terlambat membayarnya lalu harga bertambah, maka hal itu tidak diperbolehkan karena seperti riba di zaman jahiliyah. Dan tidak boleh secara syar'i persyaratan harus menyerahkan (menarik kembali) barang dagangan dalam keadaan jatuh tempo (terlambat) atas pembayarannya.

2) Fatwa Syaikhul Islam Ibnu Taimiyyah

Ibnu Taimiyah pernah ditanya tentang seorang yang membeli seekor kuda dengan harga 180 dirham. Kemudian datanglah orang lain kepadanya ingin membeli kuda tersebut dengan 300 dirham dengan dicicil selama tiga bulan, apakah jual beli itu halal. Jika orang yang membeli kuda dengan harga 180 dirham itu bertujuan untuk memanfaatkan dan memperdagangkanya, maka tida mengapa ia menjualnya kembali dengan taqsith, dengan catatan pihak penjual tidak boleh mengambil laba kecuali laba yang wajar, tidak boleh mengeruk keuntungan diatas kebutuhan orang lain yang mendesak. ${ }^{30}$

\section{c. Pengaruh Pendapatan Terhadap Keputusan pembelian Secara Taqsith.}

Pendapatan menurut ilmu ekonomi merupakan nilai maksimum yang dapat dikonsumsi oleh seseorang dalam suatu periode dengan mengharapkan keadaan yang sama pada akhir periode seperti keadaan semula. Pengertian tersebut menitikberatkan pada total kuantitatif

${ }^{28}$ Kotler Dan Armstrong, Prinsip-Prinsip ..., hlm. 218

${ }^{29}$ Hamzah Mardiansyah, "Perilaku Konsumen Dalam Belanja Secara Kredit Ditinjau Dari Etika Bisnis Islam”, Institut Agama Islam Negeri Bengkulu: Skripsi Sarjana, Fakultas Ekonomi dan Bisnis Islam, 2018, hlm. 3133

${ }^{30}$ Adi Saputra. "Faktor-Faktor Yang Mempengaruhi Perilaku Konsumen Muslim Dalam Taqsith Konsumtif (Studi: Ibu Rumah Tangga Perumahan Kemiling Permai Kota Bengkulu), Institut Agama Islam Negeri Bengkulu: Skripsi Sarjana, Fakultas Ekonomi dan Bisnis Islam, 2016, hlm.25 
pengeluaran terhadap konsumsi selama satu periode. Dengan kata lain, pendapatan adalah jumlah harta kekayaan awal periode ditambah keseluruhan hasil yang diperoleh selama satu periode, bukan hanya yang dikonsumsi. Pengertian pendapatan Menurut Robert M.Z. Lawang menyebutkan pedapatan adalah semua yang diterima oleh seseorang dalam satu bulan atau satu tahun yang dapat diukur dengan nilai ekonomi. ${ }^{31}$

Pendapatan merupakan suatu unsur penting dalam perekonomian yang berperan meningkatkan derajat hidup orang banyak melalui kegiatan produksi barang dan jasa. Besarnya pendapatan seseorang bergantung pada jenis pekerjaanya. Pendapatan adalah uang yang diterima oleh seseorang dan perusahaan dalam bentuk gaji, upah, sewa, bunga, laba dan lain sebagainya. Bersama-sama dengan tunjangan pengangguran, uang pensiun, dan lain sebagainya. Begitu juga dengan yang dinyatakan Raharja dan Manurung bahwa pendapatan merupakan total penerimaan berupa uang maupun bukan uang oleh seseorang atau rumah tangga selama periode tertentu. Dalam bentuk bukan uang yang diterima oleh seseorang misalnya berupa barang. Tunjangan beras, dan sebagainya. Penerimaan yang diterima tersebut berasal dari penjualan barang dan jasa yang dihasilkan dalam kegiatan usaha.

Sukirno menggambarkan hubungan antara pendapatan, konsumsi, dan tabungan menjadi 3 yaitu: Pertama, pada pendapatan yang rendah rumah tangga harus menggunakan harta atau tabungan masa lalu untuk membiayai pengeluaran konsumsinya. Kedua, kenaikan pendapatan menaikan pengeluaran konsumsi, biasanya pertambahan pendapatan adalah lebih tinggi dari pada pertambahan konsumsi. Ketiga, pada pendapatan yang tinggi rumah tangga menabung, disebabkan pertambahan pendapatan selalu lebih besar dari pertambahan konsumsi maka pada akhirnya rumah tangga tidak "Mengorek Tabungan" lagi.

Hasil penelitian ini menunjukkan bahwa variabel pendapatan mempunyai pengaruh yang signifikan terhadap keputusan pembelian secara taqsith konsumtif di Desa Pagardin Kecamatan Dempo Utara Kota Pagar Alam. Hal ini dapat dilihat dari hasil Uji $\mathrm{T}$ yang menghasilkan nilai signifikansi (sig) 0,017 yang kurang dari nilai probabilitas $(\alpha) 0,05$.

Penelitian ini sejalan dengan penelitian yang dilakukan Hasnira dengan tujuan untuk melihat banyaknya masyarakat Islam yang berperilaku konsumtif dan tidak lagi memperhatikan syariatnya sebagai seorang muslim. Dari hasil regresi, koefisien kolerasi (R) menunjukkan bahwa variabel bebas (pendapatan dan gaya hidup) memiliki hubungan yang erat dengan variabel terikat (konsumsi masyarakat), sedangkan koefisien determinasi (R2) menunjukan adanya pengaruh yang besar antara variabel bebas dengan variabel terikat.. ${ }^{32}$

Hasil penelitian ini juga mendukung teori dari keller bahwa keputusan pembelian yang dilakukan oleh pembeli dipengaruhi oleh adanya kepercayaan terhadap hasil pendapatan kerja Sehingga kepercayaan terhadap hasil pendapatan kerja memberikan alasan penting untuk mengambil keputusan pembelian.

Sadono Sukirno menulis bahwa pendapatan merupakan salah satu faktor terpenting yang mempengaruhi sebuah permintaan, pada hakikatnya merupakan hipotesis yang menyatakan bahwa makin tinggi pendapatan maka makin banyak permintaan terhadap barang tersebut.

\footnotetext{
${ }^{31}$ Khairiah, Kesempatan Mendapatkan Pendidikan, (Yogyakarta: Pustaka Pelajar,2018), hlm. 124

${ }^{32}$ Hasnira, "Pengaruh Pendapatan dan Gaya Hidup Terhadap Pola Konsumsi Masyarakat Wahdah Islamiyah Makassar", Universitas Islam Negeri Alauddin Makassar: Skripsi Sarjana, Fakultas Ekonomi dan Bisnis Islam, 2017.
} 
Penelitian lain yang juga mendukung hasil penelitian ini adalah penelitian yang dilakukan oleh Anissa Budi Utami Dkk dengan judul Pengaruh Harga, Pendapatan Dan Lokasi Terhadap Keputusan Pembelian Rumah Di D'kranji Residence Bekasi Barat yang hasil penelitiannya menyatakan bahwa terdapat pengaruh positif dan signifikan variabel pendapatan terhadap keputusan pembelian. ${ }^{33}$

\section{d. Pengaruh Lingkungan Sosial Terhadap Keputusan Pembelian Secara Taqsith.}

Lingkungan sosial menurut Purwanto ialah "Semua orang atau manusia lain yang mempengaruhi kita, baik secara langsung maupun tidak langsung..." Ditekankan pula oleh Setiadi dan Kolip yang dimaksud dengan lingkungan sosial adalah "Tempat atau suasana dimana sekelompok orang merasa sebagai anggotanya, seperti lingkungan kerja, lingkungan RT, lingkungan pendidikan, lingkungan pesantren, dan sebagainya”. Jadi lingkungan sosial adalah semua orang dan suasana tempat yang dapat mempengaruhi kita baik secara langsung maupun tidak langsung. Lingkungan sosial merupakan lingkungan kemasyarakatan yang mempunyai kaitan erat dengan kehidupan sehari-hari. Ada beberapa indikator-indikator yang mempengaruhi lingkungan social diantaranya Lingkungan Keluarga, Lingkungan Sekolah dan Lingkungan Masyarakat

Dalam penelitian ini lingkungan sosial mempunyai pengaruh signifikan terhadap keputusan pembelian secara taqsith konsumtif di Desa Pagardin Kecamatan Dempo Utara Kota Pagar Alam. Hal ini ditunjukkan dengan hasil signifikansi (Sig) 0,033 yang lebih kecil dari probabilitas ( $\alpha$ ) 0,05. Hasil penelitian ini dikuatkan teori dari Kotler dan Amstrong yang menyatakan bahwa lingkungan sosial memiliki kekuatan besar yang berdampak pada keputusan pembelian.

Menurut Kotler (2005:153), faktor kedua yang memengaruhi perilaku pembelian adalah faktor sosial. Faktor sosial merupakan interaksi formal maupun informal dalam masyarakat yang relatif permanen yang anggotanya menganut minat dan perilaku serupa dalam usahanya mencapai tujuan bersama. Faktor sosial terdiri dari: kelompok acuan, keluarga, peran dan status. ${ }^{34}$

Struktur sosial merupakan tatanan sosial dalam kehidupan masyarakat, yang di dalamnya terkandung hubungan timbal balik antara status dan peranan yang mengacu pada suatu keteraturan perilaku di dalam masyarakat. Struktur sosial merupakan aspek kultur (budaya) yang dapat mempengaruhi lifestyle, standar hidup dan pola konsumsi. Gejala-gejala sosial seperti ini akan menciptakan stratifikasi sosial sebagai salah satu unsur penting dalam kultur (budaya) dalam rangka mengatur perilaku. ${ }^{35}$

Hasil penelitian ini mendukung penelitian yang dilakukan oleh Utsman Afandy dengan judul Analisis Pengaruh Ekuitas Merek, Harga, dan Lingkungan Sosial Terhadap Keputusan Pembelian (Studi kasus konsumen IM3 pada mahasiswa UIN Jakarta). Hasil penelitiannya menyatakan bahwa terdapat pengaruh positif dan signifikan variabel lingkungan sosial terhadap

\footnotetext{
${ }^{33}$ Anissa Budi Utami, "Pengaruh Harga, Pendapatan Dan Lokasi Terhadap Keputusan Pembelian Rumah Di D'kranji Residence Tahap Ii Bekasi Barat”, Universitas: Politeknik Negeri Jakarta: Skripsi Sarjana ,2017

${ }^{34}$ Agung Suprayitno, "Pengaruh Faktor Sosial, Budaya, Pribadi dan Psikologi Konsumen Terhadap Keputusan Pembelian Pada Restoran Gado-gado Boplo”, Jurnal Agribisnis, Vol. IX No. 2, 2015, hlm.177 - 214

${ }^{35}$ Nurhasanah, "Hubungan Faktor Individu, Lingkungan dan fakta Sosial dengan Entrepreneurship Mahasiswa UIN Syarif Hidayatullah”, Al-Intaj, Vol. I No.1, 2017
} 
keputusan pembelian. ${ }^{36}$

Penelitian yang dilakukan Imam Ariono bertujuan untuk mengetahui pengaruh citra perusahaan, kualitas pelayanan, dan kelompok referensi secara parsial dan bersama-sama terhadap pengambilan keputusan pembelian kredit sepeda motor di PT Federal International Finance Cabang Wonosobo. Dari hasil analisis yang dilakukan diperoleh hasil bahwa variabel Citra perusahaan (X1) sebagai variabel bebas berpengaruh positif dan signifikan terhadap Pengambilan keputusan pembelian (Y). Kualitas layanan (X2) sebagai variabel bebas secara parsial tidak berpengaruh signifikan terhadap Pengambilan keputusan pembelian (Y). Kelompok referensi (X3) sebagai variabel bebas berpengaruh signifikan terhadap Pengambilan keputusan pembelian (Y) ${ }^{37}$ Hasil penelitian tersebut juga sejalan dengan penelitian ini dimana variabel lingkungan sosial berpengaruh secara signifikan terhadap keputusan pembelian secara taqsith konsumtif di Desa Pagardin Kecamatan Dempo Utara Kota Pagar Alam.

Penelitian lain yang mendukung hasil penelitian ini adalah penelitian yang dilakukan Mardiyono dengan Tujuan untuk mengetahui apakah terdapat pengaruh dari variabel-variabel gaya hidup, lingkungan sosial dan budaya terhadap keputusan pembelian di pasar modern. Dari Hasil penelitian ini menyatakan bahwa variabel gaya hidup, lingkungan sosial dan budaya berpengaruh secara terhadap keputusan pembelian di pasar modern. Baik secara parsial maupun bersama-sama. ${ }^{38}$

\section{e. Pengaruh Pendapatan dan Lingkungan Sosial Secara Simultan Berpengaruh Signifikan Terhadap Keputusan Pembelian Secara Taqsith}

Hasil dari perhitungan regresi linear menunjukkan bahwa pendapatan dan lingkungan sosial secara simultan atau bersama-sama berpengaruh signifikan terhadap keputusan Pembelian Secara Taqsith Konsumtif Pada Masyarakat Desa Pagardin Kecamatan Dempo Utara Kota Pagar Alam. Hal ini dibuktikan dalam uji F dengan nilai sig yang kurang dari $\alpha(0,05)$ yaitu 0,000 . Artinya bahwa pendapatan dan lingkungan sosial secara simultan atau bersama-sama berpengaruh signifikan terhadap keputusan Pembelian Secara Taqsith Konsumtif Pada Masyarakat Desa Pagardin Kecamatan Dempo Utara Kota Pagar Alam.

Dari hasil uji determinasi yang menghasilkan nilai R Square sebesar 0,218 atau 21,8 \% menunjukkan bahwa dalam penelitian ini keputusan pembelian secara taqsith dipengaruhi oleh variabel pendapatan dan variabel lingkungan sosial sebesar $21,8 \%$ yang artinya bahwa kontribusi pengaruh dari kedua variabel tersebut rendah dan sisahnya sebesar 78,2 \% menunjukkan bahwa variabel keputusan pembelian secara taqsith dipengaruhi oleh variable lain yang tidak diteliti dalam penelitian ini.

${ }^{36}$ Utsman Afandy, "Pengaruh Ekuitas Merek, Harga, dan Lingkungan Sosial Terhadap Keputusan Pembelian (Studi kasus konsumen IM3 pada mahasiswa UIN Jakarta”, Universitas Islam Negeri Syarif Hidayatullah, Skripsi Sarjana: 2008

${ }^{37}$ Imam Ariono, "Pengaruh Citra Perusahaan, Kualitas Pelayanan Dan Kelompok Referensi Terhadap Pengambilan Keputusan Pembelian Kredit Sepeda Motor Di Pt. Federal International Finance Cabang Wonosobo", Jurnal PPKM, Vol. I No. 13, 2018

${ }^{38}$ Mardiyono, "Pengaruh Gaya Hidup, Lingkungan Sosial, Dan Budaya Terhadap Keputusan Pembelian Di Pasar Modern (Studi Kasus Pada Mahasiswa Iain Purwoketo)”, Institut Agama Islam Negeri Purwokerto: Skripsi Sarjana, Fakultas Ekonomi dan Bisnis Islam, 2018 


\section{KESIMPULAN}

Dari hasil penelitian dapat disimpulkan bahwa: (1) Variabel pendapatan berpengaruh signifikan terhadap keputusan pembelian secara taqsith konsumtif pada masyarakat Desa Pagardin Kecamatan Dempo Utara Kota Pagar Alam. Hal ini dibuktikan dari hasil Uji T dengan nilai signifikansi sebesar (sig) $0,017<(\alpha)$ 0,05 sehungga hipotesis pertama diterima; (2) Variabel lingkungan sosial berpengaruh signifikan terhadap keputusan pembelian secara taqsith konsumtif pada masyarakat Desa Pagardin Kecamatan Dempo Utara Kota Pagar Alam. Hal ini dibuktikan dari hasil Uji T dengan nilai signifikansi sebesar (sig) $0,033<(\alpha)$ 0,05 sehungga hipotesis kedua diterima; (3) Variabel pendapatan dan lingkungan sosial secara simultan berpengaruh signifikan terhadap keputusan pembelian secara taqsith konsumtif pada masyarakat Desa Pagardin Kecamatan Dempo Utara Kota Pagar Alam. Hal ini dibuktikan dari hasil Uji F dengan nilai signifikansi sebesar (sig) 0,000 yang kurang dari $\alpha(0,05)$, sehingga hipotesis ketiga diterima.

\section{B. DAFTAR PUSTAKA}

Abdullah, Thamrin. Francis Tantri. 2012. Manajemen Pemasaran. Depok: PT Raja Grafindo Persada

Alman, Buchari. 2013. Manajemen Pemasaran dan Pemasaran Jasa. Bandung: Alfabeta

Agung Suprayitno. 2015. "Pengaruh Faktor Sosial, Budaya, Pribadi dan Psikologi Konsumen Terhadap Keputusan Pembelian Pada Restoran Gado-gado Boplo”, Jurnal Agribisnis, Vol. IX No. 2

Amanaturrohim, Hanifah. 2019."Pengaruh Pendapatan Dan Konsumsi Rumah Tangga Terhadap Kesejahteraan Keluarga Petani Penggarap Kopi Di Kecamatan Candiroto Kabupaten Temanggung”. Skripsi

Armstrong, Kotler. 2001. Prinsip-Prinsip Pemasaran. Jakarta: PT Gelora Aksara Pratama

Ariono, Imam. 2018. "Pengaruh Citra Perusahaan, Kualitas Pelayanan Dan Kelompok Referensi Terhadap Pengambilan Keputusan Pembelian Kredit Sepeda Motor Di Pt. Federal International Finance Cabang Wonosobo”. Jurnal PPKM. Vol. I No. 13

Ash-Shadr, Muhammad Baqir. 2008. Buku Induk Ekonomi Islam. Jakarta: Zahra

Chrisnawati, Dian. Sri Muliati. 2011. "Faktor-Faktor Yang Mempengaruhi Perilaku Konsumtif Remaja Terhadap Pakaian (Studi Kasus Pada Remaja Berstatus Sosial Ekonomi Rendah)". Jurnal Skripsi, Vol. II No. 1

Danil, Mahyu. 2013. "Pengaruh Pendapatan Terhadap Tingkat Konsumsi Pada Pegawai Negeri Sipil Dikantor Bupati Kabupaten Bireuen.” Jurnal Manajemen. Vol. IV No. 7

Daryanto. 2011. Sari Kuliah Manajemen Pemasaran. Bandung: PT Sarana Tutorial Nurani Sejahtera

Ginting, Nembah F. Hartimbul. 2010. Manajemen Pemasaran. Cet. 1. Bandung: CV Yrama Widya

Haloho, Elizabeth. 2018. "Pengaruh Komunikasi Pemasaran Terhadap Keputusan Pembelian Produk Kredit Pensiun di PT. Bank Sumut Kc. Kampung Lalang Medan”. Jurnal Mutiara Manajemen. Vol. III No. 01

Hartono, Tony. 2006. Mekanisme Ekonomi Dalam Konteks Ekonomi Indonesia. Bandung: Remaja Rosdakarya

Hasnira. 2017. "Pengaruh Pendapatan dan Gaya Hidup Terhadap Pola Konsumsi Masyarakat Wahdah Islamiyah Makassar”. Skripsi: Islam Negeri Alauddin Makassar

Henrietta, P. 2017. "Impulsive Buying”Pada Dewasa Awal Di Yogyakarta”. Jurnal Psikologi Universitas Sanata Dharma Yogyakarta 
Iskandar. 2017. "Pengaruh Pendapatan Terhadap Pengeluaran Rumah Tangga Miskin Di Kota Langsa". Jurnal Samudra Ekonomika. Vol. I No. 2

Juwita, Sendy Octavia Puspa. 2017. “ Pengaruh Kualitas Layanan Terhadap Keputusan Pembelian Kredit Kepemilikan Rumah Pada Btn Kantor Cabang Surabaya Kcp Mojokerto". Jurnal Pendidikan Tata Niaga. Vol. I No. 01

Khairiah. 2018. Kesempatan Mendapatkan Pendidikan. Yogyakarta: Pustaka Pelajar Mannan, Muhammad Abdul. 1992. Ekonomi Islam: Teori dan Praktek. Jakarta: Intermasa

Mardiansyah, Hamzah. 2018. Perilaku Konsumen Dalam Belanja Secara Kredit Ditinjau Dari Etika Bisnis Islam. Skripsi

Suryani, Mardian dan Siti achira. 2019 "Gaya Hidup Hedonisme Konsumsi Ditinjau dari Perspektif Ekonomi Islam”. Al-Intaj, Vol.V No.2

Mardiyono. 2018. "Pengaruh Gaya Hidup, Lingkungan Sosial, Dan Budaya Terhadap Keputusan Pembelian Di Pasar Modern (Studi Kasus Pada Mahasiswa Iain Purwoketo)”. Universitas: Institut Agama Islam Negeri Purwokerto: Skripsi Sarjana

Morrisan. 2010. Perilaku Komunikasi Pemasaran Terpadu. Jakarta: Kencana Prenada Media Group

Naf'an. 2014. Ekonomi Makro Tinjauan Syariah. Yogyakarta: Graha Ilmu

Nitisusastro, Mulyadi. 2013. Perilaku Konsumen Dalam Perspektif Kewirausahaan. Bandung: Alfabeta

Noor, Juliansyah. 2011. Metodologi Penelitian. Skripsi,Tesis,Disertai, Dan Karya Ilmiah. Jakarta: Prenadamedia

Nurhasanah. 2017. "Hubungan Faktor Individu, Lingkungan dan fakta Sosial dengan Entrepreneurship Mahasiswa UIN Syarif Hidayatullah", AL Intaj, Vol.I No.1

Utami Anissa Budi. 2017. "Pengaruh Harga, Pendapatan Dan Lokasi Terhadap Keputusan Pembelian Rumah Di D’kranji Residence Tahap Ii Bekasi Barat”. Skripsi: Politeknik Negeri Jakarta

Purba, Jonny. 2002. "Pengelolaan Lingkungan Sosial.” Jakarta: Yayasan Obor Indonesia

Rosa, Andartika. 2018. "Pengaruh "Financial Knoeledge", Tingkat Pendapatan Terhadap Perilaku Pengelolaan Uang Dengan "Self Control" Sebagai Variable Mediasi". Jurnal Ilmiah Sekolah Tinggi Ilmu Ekonomi Perbanas Surabaya

Sangadji, Etta Mamang. Sopiah. 2013. Perilaku Konsumen. Yogyakarta: C.V Andi Offset

Saputra, Adi. 2006. Faktor-Faktor Yang Mempengaruhi Perilaku Konsumen Muslim Dalam Taqsith Konsumtif (Studi: Ibu Rumah Tangga Perumahan Kemiling Permai Kota Bengkulu). Universitas: IAIN Bengkulu. Skripsi Sarjana. Fakultas Ekonomi dan Bisnis Islam

Siregar, Syofian. 2013. Metode Penelitian Kuantitatif. Jakarta: Kencana

Sugiono. 2013. Metode Penelitian Kuantitatif Dan Kualitatif Dan r\&d. Bandung: Al-fabeta

Sukirno, Sadono. 2006. Makro Ekonomi Teori Pengantar. Jakarta: Raja Grafindo Persada

Sunyoto, Danang. 2012. Konsep Dasar Riset Pemasaran dan Perilaku Konsumen. Yogyakarta: CAPS

Suparmoko, M. 2011. Teori Ekonomi Mikro. Yogyakarta: BPFE

Suroso. Rendro Adi Widigdo. 2005. Pengetahuan Sosial Ekonomi. Solo: Tiga Serangkai Pustaka Mandiri

Suyanto, Bagong. 2013. Sosiologi Ekonomi Kapitalise dan Konsumsi Di Era Masyarakat PotsModernisme. Jakarta: Kencana

Syarifudin, Tohari. dkk. 1994. Pegangan Ekonomi Untuk Smu Kelas 1. Bandung: CV. ARMICO.

Tamara, Riana Monalisa. 2016. "Peranan Lingkungan Sosial Terhadap Pembentukan Sikap Peduli Lingkungan Peserta Didik Di Sma Negeri Kabupaten Cianjur”. Jurnal Pendidikan Geografi. Vol. XVI No. 1

Walker, dkk. 2000. Manajemen Pemasaran: Suatu Pendidikan Strategis Dengan Orientasi 
Global. Ed.2. Jakarta: Erlangga 